\title{
Genome Size Variation in Elms (Ulmus spp.) and Related Genera
}

\author{
Alan T. Whittemore ${ }^{1}$ \\ U.S. National Arboretum, 3501 New York Avenue NE, Washington, DC \\ 20002-1958
}

\section{Zheng-Lian Xia}

U.S. National Arboretum, Room 124, Building 010A, BARC-West, 10300 Baltimore Avenue, Beltsville, MD 20705 Additional index words. DNA content, elm, flow cytometry, Hemiptelea, Planera, Ulmus,
Zelkova

\begin{abstract}
Elms (Ulmus spp.) are iconic street and landscape trees, but their use is currently limited by susceptibility to disease, especially Dutch elm disease (DED). Improved access to disease-resistant germplasm will be of great benefit for ongoing breeding and selection programs, but these programs have been limited historically by uncertain relationships among Ulmus species, especially the North American species and their putative Old World relatives. Estimates of genome size from 28 species representing both subgenera of Ulmus (subg. Ulmus and subg. Oreoptelea) and six species in the related small genera Zelkova, Hemiptelea, and Planera were estimated using flow cytometry. Genome-size estimates were calibrated using seven elms with known chromosome counts. Results strongly supported the subgeneric classification of Wiegrefe et al. Monoploid genome size was found to be quite constant within the subgenera of Ulmus they recognized and within the small genera, and polyploidy is uncommon in these plants. However, there are consistent differences in genome size between the subgenera of Ulmus and between them and the smaller genera, and these differences can be used to place species in their proper taxon, knowledge which can be useful in identifying disease-resistant germplasm that may be compatible with Ulmus americana and other North American taxa. Two Asian species that have sometimes been considered to be related to North American species now placed in subg. Oreoptelea were tested. The Himalayan Ulmus villosa has a much smaller genome than either of the subgenera, indicating that its relationship with other elms is rather remote. It may be a source of novel genes in Ulmus, but our results indicate it is not close to $U$. americana or other New World species. In contrast, results from the rare Chinese species Ulmus elongata support its placement in subg. Oreoptelea. It is the only close relative of the North American elms that is native to Asia, where DED is believed to have originated, and its response to DED infection should be evaluated.
\end{abstract}

The genus Ulmus L. (the elms) holds a preeminent place in North American and European horticulture. Ulmus spp. have served as iconic street and landscape trees in both of these continents (Campanella, 2003; Dunn, 2000). Elms have also served many other purposes in other Northern Hemisphere cultures (Heybroek, 2015). The genus consists of 20-40 species, widespread in the north temperate zone and extending south into tropical mountains in both hemispheres (Fu et al., 2004; Sherman-Broyles, 1997).

The closest relatives of Ulmus are three small genera native to temperate regions of

Received for publication 1 Nov. 2016. Accepted for publication $21 \mathrm{Feb} .2017$.

We thank Michael S. Dosmann and Kathryn Richardson (Arnold Arboretum, Jamaica Plain, MA) and Matt Lobdell, Kris Bachtell, and Marlene Hahn (Morton Arboretum, Lisle, IL) for providing plant material for analysis from their living collections. Susan Bentz and Kevin Conrad provided assistance in various ways.

${ }^{1}$ Corresponding author. E-mail: Alan.Whittemore@ ars.usda.gov. the Northern Hemisphere, Zelkova Spach, Hemiptelea Planch., and Planera J. F. Gmel. (Wiegrefe et al., 1998). The genus Zelkova Spach, with five or six species disjunct across Eurasia (Denk and Grimm, 2005), has also become important in American horticulture. The other two genera have one species each. Hemiptelea davidii (Hance) Planch., native to northeastern China and Korea, is used as a small tree or clipped into a thorn hedge in China, but it is not used in American horticulture. Genotypes from Inner Mongolia, China, are noted for their red fall color (Deligen, 2006), but have not yet been introduced to the West. Planera aquatica J. F. Gmel., native to seasonally flooded riverbottoms in the southeastern United States (Godfrey, 1988), has been little used outside its native range, but it grows as a small tree in gardens and may be valuable for its tolerance of heat, flooding, and poorly drained soils.

Studies of chromosome number and structure have found very limited genomic divergence in the group. All members of these four genera that have been studied have chromosome numbers based on $x=14$, with no aneuploid variation (Goldblatt and
Johnson, 1979; Oginuma et al., 1990). Polyploidy is rare, and it is known from only two species. $U$. americana is known to include tetraploids with $2 n=56$ (Karrfalt and Karnosky, 1975) as well as diploids (Whittemore and Olsen, 2011), and Hemiptelea davidii has two reported chromosome numbers, $2 n=56(\mathrm{Fu}$ et al., 1998) and $2 n=84$ (Oginuma et al., 1990), presumably tetraploid and hexaploid numbers based on $x=14$.

Elms in North America and Europe have suffered high mortality from two diseases: DED, caused by several species of fungi native to East Asia (Brasier, 1991, 2001), and elm yellows (elm phloem necrosis), caused by a phytoplasma (Mittempergher, 2000; Sinclair, 2000). Because of the horticultural importance of elms, there has been much interest in selection and breeding for disease tolerance in the genus (Dunn, 2000).

To date, elm breeding has mostly involved species native to Europe and North America, although the fungi that cause DED are native to eastern Asia; the North American and European elm species have low levels of resistance. Although Ulmus is most diverse in East Asia, with 21 species native to China alone (Fu et al., 2004), until recently, relatively little germplasm from this area has been available to Western breeders. The work of Fu et al. (2004), which reduces several of the names used in previous literature, including $U$. japonica (Rehder) Sarg. 1907 not Sieb. 1830, U. propinqua Koidz., and U. wilsoniana C.K. Schneid, to synonyms of $U$. davidiana var. japonica (Rehder) Nakai, indicates that the level of diversity is even lower than what was previously thought; thus, Warren (2000) lists four Asian elm species (U.japonica, U. parvifolia, U. pumila, and $U$. wilsoniana) that have contributed to commercial cultivars now available in the west, but using the taxonomy of $\mathrm{Fu}$ et al. (2004), this list includes only three valid species, $U$. davidiana var. japonica, $U$. parvifolia, and U. pumila, which are now recognized.

In the 1980s and 1990s, much new elm germplasm was introduced to North America from China through the efforts of the late George Ware (Ware, 1995). Chromosome counts for many of these introductions were published, but the plants were juvenile and not flowering at the time they were studied (Santamour and Ware, 1997). Most of these trees are now producing fruit and showing adult bark characteristics, both of which are important for identification. In addition, taxonomic treatments of the Chinese species have been published (Fu et al., 1998, 2004), allowing more accurate identifications of the Asian species. It has thus been possible to correct some misidentifications in Ware's Asian germplasm.

Unfortunately, the relevance of this material to research and breeding on $U$. americana is uncertain. The difficulty of crossing tetraploid $U$. americana with other Ulmus spp. has often been attributed to ploidy differences, but Ager and Guries (1982) and Bob et al. (1986) demonstrate that crossing 
barriers between $U$. americana and several diploid elm species are not ploidy-related. Studies of interspecific hybridization in Ulmus have shown that different combinations of parents show different levels of compatibility (Hans, 1981; Townsend, 1975), but the planning of controlled breeding programs was limited in the past because traditional classifications of Ulmus did not seem to reflect relationships adequately (Hans, 1981).

The infrageneric classification of Ulmus has now been placed on a more solid footing by the work of Wiegrefe et al. (1994). All elms available to these authors were placed in two well-marked subgenera, Ulmus subg. Ulmus and Ulmus subg. Oreoptelea (Spach) Planch. This has presented a problem for the American elm breeders. U. americana belongs to subg. Oreoptelea, which is predominately North American (only a single Old World species, the European U. laevis, was placed here by Wiegrefe et al.), whereas all of the elm species studied by Wiegrefe et al. that are native to eastern Asia (the area where the fungi causing DED are native) belong to subg. Ulmus. Past attempts to breed resistance to DED from other elm species into $U$. americana have not met with success, but they involved crossing $U$. americana (of subg. Oreoptelea) with species of subg. Ulmus (especially U. pumila). Quite a few hybrid combinations have been reported to yield at least occasional fruit (Townsend, 1975), but the only hybrid cultivars that have been released are hybrids among the European and Asian species of subg. Ulmus (Warren, 2000), indicating limited genetic compatibility between the subgenera.

However, two Asian species that were not available to Wiegrefe et al. have been placed by some authors in sect. Chaetoptelea (Liebm.) C.K. Schneid., a group of species that falls within Ulmus subg. Oreoptelea as defined by Wiegrefe et al. (1994). If true, then sources of resistance genes that are more compatible with the North American elms may be available in the genus. The Himalayan species $U$. villosa was placed in this group by Grudzinskaya (1974) and Richens (1983), based on the characteristics of its fruit (its inflorescence resembles that of subg.
Ulmus), whereas $\mathrm{Fu}$ et al. (1979, 1998) placed the Chinese species $U$. elongata in this group, based on the characteristics of its inflorescence and fruit. If these placements are correct, U. villosa and U. elongata would fall within Ulmus subg. Oreoptelea as defined by Wiegrefe et al. (1994), and these poorly known species would be the only close relatives of $U$. americana native to Asia, where DED is believed to have originated. In this case, it would be worth investigating them as possible sources of resistance genes that would be more compatible with the genetic background of $U$. americana and other species of subg. Oreoptelea than the species of subg. Ulmus, the only DED-resistant species that have been studied to date. Santamour (1979) presented evidence that $U$. villosa shows resistance to DED, but DED resistance has never been studied in U. elongata (Smalley and Guries, 2000). Finding other characteristics that distinguish the subgenera could confirm or refute the placement of these two species in subg. Oreoptelea, which in turn could provide direction for future study of how elm species respond to these diseases and for future elm breeding.

Flow cytometry provides a measure of nuclear DNA content and a method for examining genomic diversification that is much faster and easier than chromosome counts. Flow cytometry can be carried out on most tissues of the plant, and it provides a different view of diversity in a group of plants than chromosome number. A recent flow cytometry survey of $U$. americana (Whittemore and Olsen, 2011) revealed unexpected variation in the species. It is desirable to extend this work for several reasons. First, the study of Whittemore and Olsen quantified the DNA by staining with 4',6-diamidino-2-phenylindole (DAPI) and calibrated the measurements with a single chromosome count. The staining reaction of DAPI is specific to AT bps, so it gives an accurate estimate of total DNA only if the percent AT in the genome is similar in the study organism and the internal standard (Dolezel et al., 2007a). This is not a problem if DNA is visualized using an intercalating dye such as propidium iodide (PI) rather than a stain. Carrying out flow cytometry using PI and calibrating the work using additional trees with known chromosome numbers will give us a firmer understanding of variation in genome size. In addition, a broad survey of nuclear DNA content in Ulmus and related genera using flow cytometry could provide more information on the distribution of natural polyploids, and reveal differences in genome size between the genera and subgenera. Knowledge of genome-size variation, in turn, can help to place species whose relationships are uncertain. In view of the importance of Ulmus and Zelkova in American horticulture, and especially the need to find disease-resistant germplasm, a broad survey of Ulmus and related genera using flow cytometry was conducted, emphasizing species of uncertain relationship, and germplasm that has only been recently introduced to American horticulture and not well characterized.

\section{Materials and Methods}

Fruit and leaf tissue of Ulmus, Zelkova, Hemiptelea, and Planera were collected from trees in the living collections of the U.S. National Arboretum or from wild plants in the United States, and fresh leaves for analysis were supplied by collaborators from the collections of Arnold Arboretum (Jamaica Plain, MA) and Morton Arboretum (Lisle, IL). Voucher specimens are preserved in the herbarium of the U.S. National Arboretum (Index Herbariorum acronym: NA; Thiers, 2016). The tissue for analysis was stored on ice or in the refrigerator and analyzed when fresh. Whenever possible, at least three accessions per species were sampled. Both $U$. bergmanniana C.K. Schneid. and $U$. gaussenii W. C. Cheng have been reported to be cultivated in North America, but all seen cultivated specimens that were named as these species were found to be misidentified, so the species could not be sampled. Samples included seven elms with known chromosome counts previously reported by Santamour (1969), Santamour and Ware (1997), and Sherald et al. (1994). The identity and source of all plant material are listed in Tables 1 and 2.

Table 1. DNA content estimates for accessions with known chromosome counts.

\begin{tabular}{|c|c|c|c|c|c|}
\hline Taxon & Individual $^{\mathrm{z}}$ & $\begin{array}{c}\text { Reported chromosome } \\
\text { number }\end{array}$ & $\begin{array}{l}\text { Source of chromosome } \\
\text { number }\end{array}$ & $2 C^{y}$ & $1 C x^{x}$ \\
\hline \multicolumn{6}{|l|}{ Ulmus subg. Oreoptelea } \\
\hline Ulmus americana Jefferson & NPS 3-487, NA 62001 & $2 n=3 x=42$ & Sherald et al. (1994) & $4.652 \mathrm{pg}$ & $1.551 \mathrm{pg}$ \\
\hline Ulmus elongata & R94-6, NA 68995 & $2 n=2 x=28$ & Santamour and Ware (1997) & $3.00 \mathrm{pg}$ & $1.500 \mathrm{pg}$ \\
\hline \multicolumn{6}{|l|}{ Ulmus subg. Ulmus } \\
\hline Ulmus castaneifolia & R94-11, NA 68978 & $2 n=2 x=28$ & Santamour and Ware (1997) & $3.838 \mathrm{pg}$ & $1.919 \mathrm{pg}$ \\
\hline Ulmus chenmoui & R93-117, NA 76222 & $2 n=2 x=28$ & Santamour and Ware (1997) & $3.979 \mathrm{pg}$ & $1.990 \mathrm{pg}$ \\
\hline $\begin{array}{l}\text { Ulmus davidiana var. davidiana } \\
\quad \text { (as } U \text {. gaussenii) }\end{array}$ & R94-8, NA 76224 & $2 n=2 x=28$ & Santamour and Ware (1997) & $3.876 \mathrm{pg}$ & $1.938 \mathrm{pg}$ \\
\hline Ulmus lamellosa (as U. taihangshanica) & R95-21, NA 68992 & $2 n=2 x=28$ & Santamour and Ware (1997) & $3.955 \mathrm{pg}$ & $1.978 \mathrm{pg}$ \\
\hline Ulmus macrocarpa & PI 138018, NA 1847 & $2 n=2 x=28$ & Santamour (1969) & $3.987 \mathrm{pg}$ & $1.993 \mathrm{pg}$ \\
\hline
\end{tabular}

${ }^{\mathrm{z}}$ Accession numbers beginning in R are Morton Arboretum research numbers (used by Santamour and Ware, 1997); beginning in PI, USDA PI numbers (used by Santamour, 1969); beginning in NPS, National Park Service numbers (used by Sherald et al., 1994); beginning in NA, National Arboretum accession numbers (current database numbers for these accessions). All samples are currently growing at the U.S. National Arboretum.

${ }^{\mathrm{y}} 2 \mathrm{C}$ designates the measured DNA content of one nucleus (Dolezel et al., 2007b).

${ }^{\mathrm{x}} 1 C x$ designates the inferred DNA content of a haploid chromosome set (Dolezel et al., 2007b). 
Table 2. Nuclear genome-size estimates for 96 accessions (34 species) of Ulmus and three related genera. Samples are in the same order as in Fig. 1.

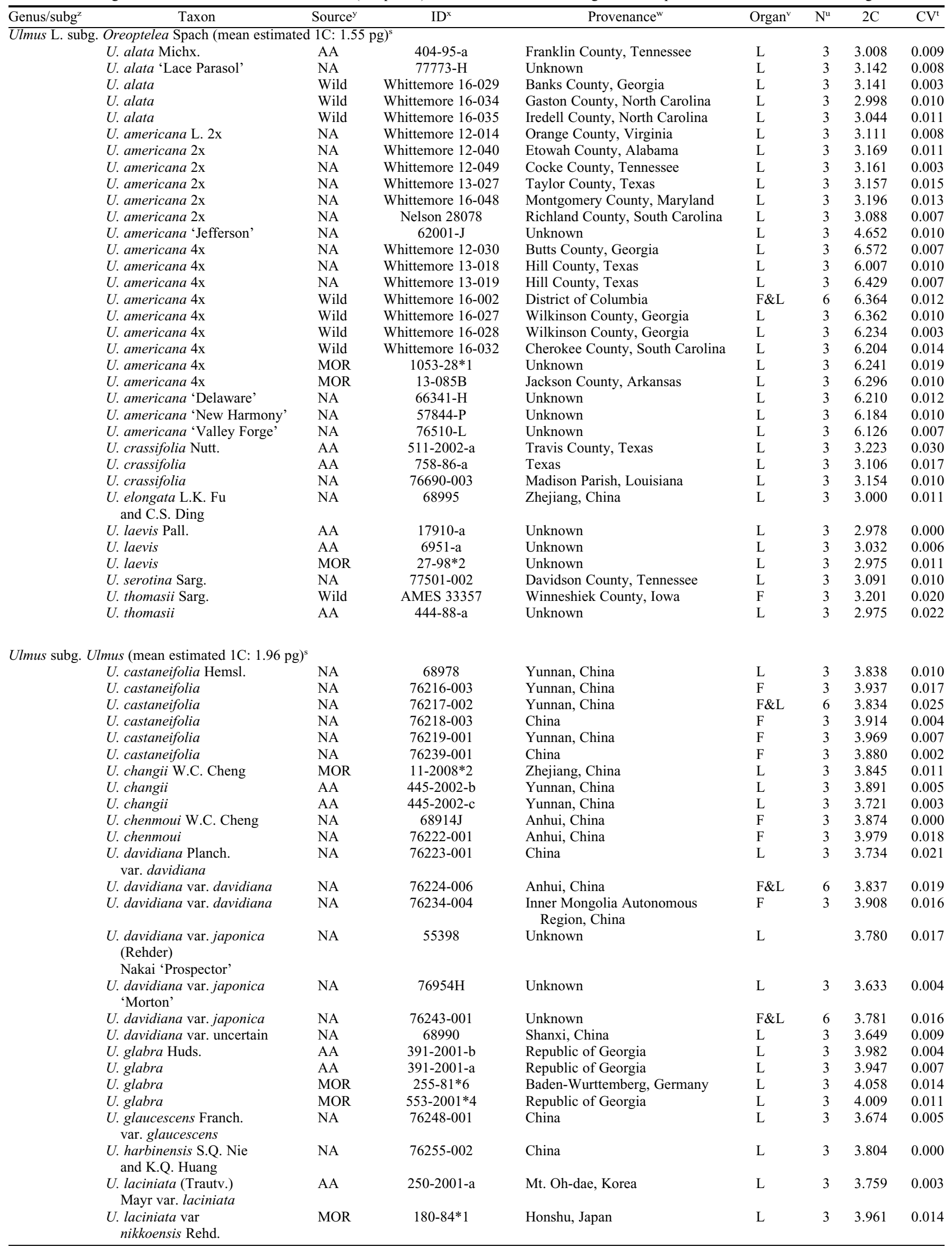


Table 2. (Continued) Nuclear genome-size estimates for 96 accessions (34 species) of Ulmus and three related genera. Samples are in the same order as in Fig. 1.

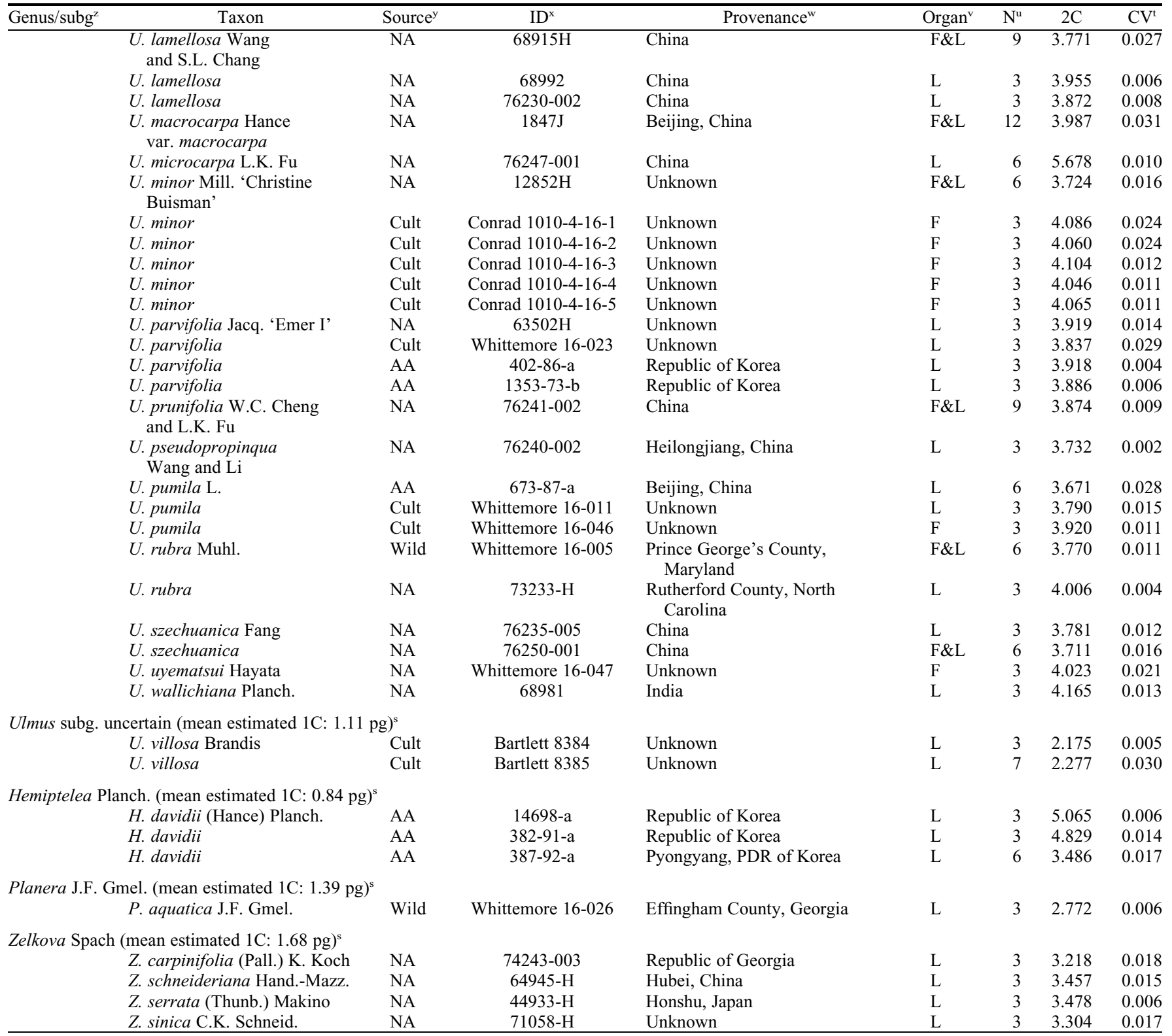

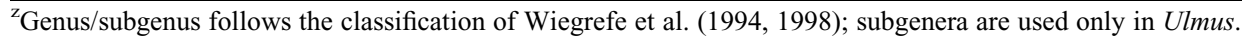

${ }^{y}$ Source is Arnold Arboretum (AA), Morton Arboretum (MOR), U.S. National Arboretum (NA), other cultivated source (cult), or collected directly from wild plants (wild).

${ }^{\mathrm{x}} \mathrm{ID}$ is the garden accession number or herbarium voucher (collector and number).

"Provenance is the site where the germplasm (for cultivated trees) or tissue (for wild-collected material) was collected; "Unknown" includes cultivated material not collected directly from the wild and cultivated trees of unknown provenance.

${ }^{\mathrm{v}}$ Organ is leaf $(\mathrm{L})$, fruit $(\mathrm{F})$, or both (L and F).

${ }^{\mathrm{u}} n$ is the number of independent runs carried out, $2 \mathrm{C}$ is the estimated nuclear DNA content.

${ }^{\mathrm{t}} \mathrm{CV}$ is the $\mathrm{CV}$ among the runs for one sample.

${ }^{5}$ Mean of all IC values inferred for the genus or subgenus. Ploidy is diploid except for $U$. americana marked $4 x$. two triploids (U. americana 'Jefferson' and U. microcarpa NA 76247-001) and Hemiptelea (see text for inferred ploidy of Hemiptelea samples).

Flow cytometry was carried out on a Sysmex CyFlow Space flow cytometer using the extraction buffer and staining buffer from the Sysmex Cystain PI Absolute P kit (Sysmex, Görlitz, Germany) according to the manufacturer's instructions. Fresh leaf tissue of Glycine $\max$ 'Williams 82', with a monoploid genome size [1Cx-value: DNA content of the monoploid chromosome set (Greilhuber et al., 2005)] of $1.13 \mathrm{pg}$ (Chesnay et al., 2007), was used as an internal standard. [Accessions of $U$. villosa overlapped with Glycine $\max$ 'Williams 82', so size estimates were confirmed using a second internal standard, Zea mays 'CE-177', with a monoploid chromosome set of $2.715 \mathrm{pg}$ (Dolezel et al., 2007a)]. About $0.5 \mathrm{~cm}^{2}$ of Ulmus tissue was cochopped with leaf tissue of the internal standard $\left(<0.5 \mathrm{~cm}^{2}\right)$ with a doublesided razor blade for 30 to $60 \mathrm{~s}$ in $400 \mu \mathrm{L}$ of extraction buffer, then incubated for $\approx 60 \mathrm{~s}$. Suspensions were filtered through $50 \mu \mathrm{m}$ nylon mesh filters, and nuclei were stained with $1.6 \mathrm{~mL}$ of staining buffer containing PI and RNAase A, then incubated for about $2 \mathrm{~h}$ protected from light at room temperature. The nuclear suspension was analyzed on the flow cytometer with fluorescence excitation provided by a laser emitting at $488 \mathrm{~nm}$.

The mean fluorescence of each sample was compared with mean fluorescence of the internal standard to determine holoploid genome size [ $2 C$-value: DNA content of the whole complement of chromosomes characteristic for the organism, irrespective of the ploidy level (Greilhuber et al., 2005)]. At 

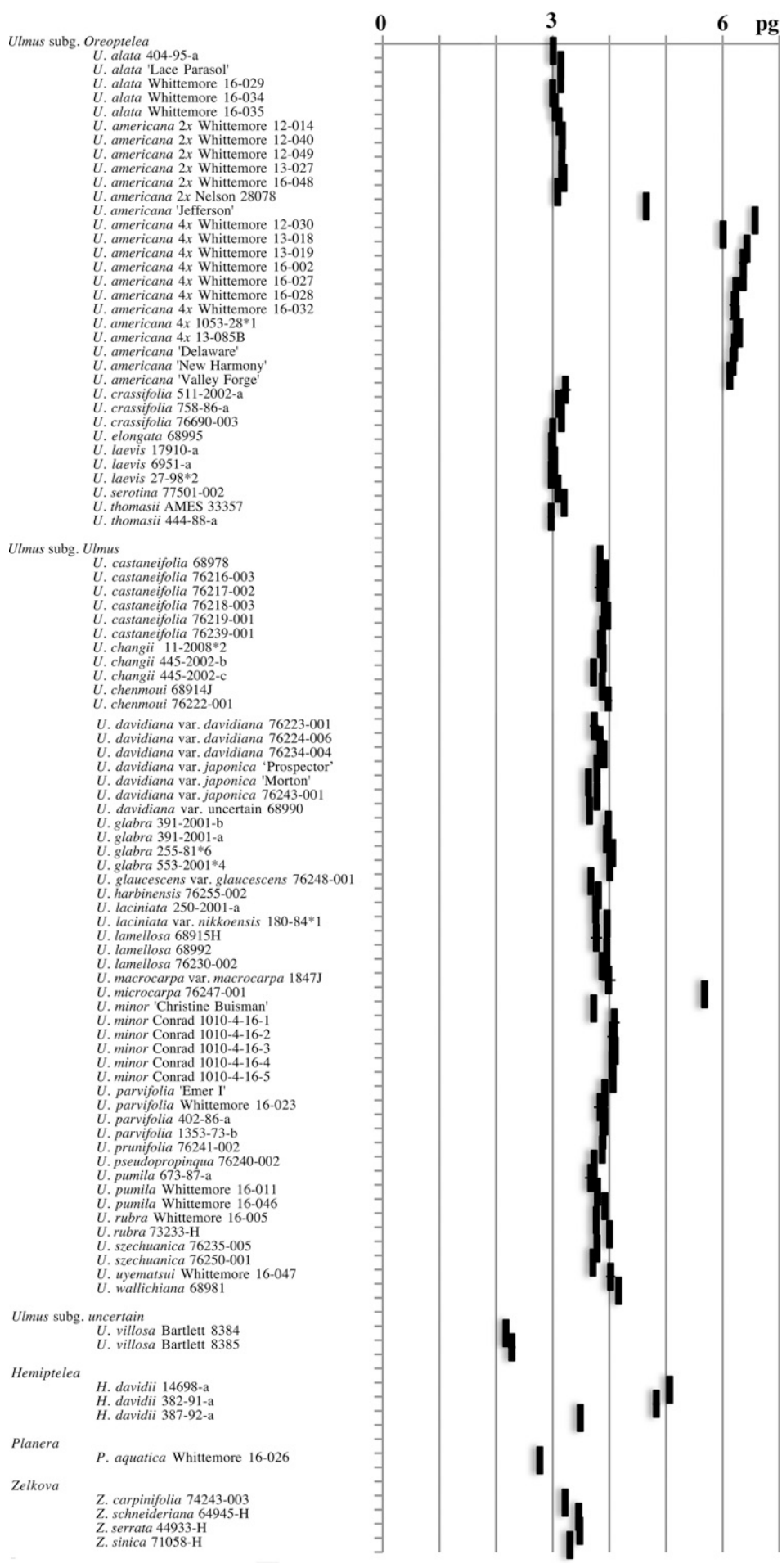

Fig. 1. Nuclear DNA content (2C value) for 96 accessions ( 34 species) of Ulmus and three related genera. Samples are in the same order as in Table 2. Error bars are plus or minus one SD; markers are without visible error bars if the $\mathrm{SD}$ is less than the width of the marker. $\mathrm{SD}=$ standard deviation.

least 3000 nuclei were counted to determine the ratio of sample peak to the internal standard and, thus, nuclear DNA content $[2 \mathrm{C}$ $\mathrm{pg}=($ sample peak/internal standard peak $) \times$ $(2 \times 1.13 \mathrm{pg})]$. A minimum of three independent preparations were run from each plant sampled, and the mean and coefficient of variation $(\mathrm{CV})$ were calculated for all runs with each sample. Ploidy level, thus DNA content of the monoploid chromosome set (1Cx-value), was determined by comparison with seven elms of known chromosome number (see above). For selected specimens, separate analyses were done on fruit and expanding leaves, or on fruit (spring) and late-summer leaves, to test whether results from different organs and different seasons are comparable.

\section{Results and Discussion}

Seven elms were available with known chromosome counts previously reported by
Santamour (1969), Santamour and Ware (1997), and Sherald et al. (1994), representing two species of Ulmus subg. Oreoptelea and five species of Ulmus subg. Ulmus. Flow cytometry was used to measure nuclear DNA content (2Cvalue) for these seven plants. Monoploid DNA content (1C) was calculated from the $2 \mathrm{C}$ value assuming a haploid chromosome number of $x=$ 14. Results are given in Table 1. Estimates of monoploid genome size $(1 C x)$ were consistent within subgenera, but estimates for species of subg. Ulmus were consistently about $30 \%$ larger than they were for subg. Oreoptelea.

The genome size of one of these trees, $U$. americana 'Jefferson' (NPS 3-487, NA 62001), was previously measured using DAPI rather than PI as the stain (Whittemore and Olsen, 2011). Size estimates using the two stains were similar $(2 \mathrm{C}=4.652 \mathrm{pg}$ using PI, 2C $=4.71 \mathrm{pg}$ using DAPI), providing preliminary indications that the proportions of AT and GC bps in the Ulmus genome are about similar to proportions in the plant used as the size standard, Glycine max 'Williams 82 ' $(65.25 \%$ AT, $34.75 \%$ GC; Song et al., 2010). This provides evidence that as long as Glycine max 'Williams 82 ' is used as the internal standard, no correction needs to be applied when comparing size estimates using PI and DAPI, at least for U. americana.

Estimates of nuclear DNA content were obtained from a total of 96 individuals, representing 34 species and four genera. Size estimates from multiple runs on the same sample were consistent, with among-run CVs averaging $1.2 \%$, and $93 \%$ of the among-run CVs below $2.5 \%$. Results obtained from fruit, expanding leaves, and late-summer leaves were similar (data not shown).

Although the base chromosome number is constant in these four genera, flow cytometry does reveal divergence in genome size among the genera and subgenera. These results provide strong support for the subgenera as defined by Wiegrefe et al. (1994). In the full data set, as in the seven species of known chromosome count, estimates of monoploid genome size $(1 C x)$ were consistent within Wiegrefe et al.'s subgenera, but estimates for species of subg. Ulmus were consistently about 30\% larger than they were for subg. Oreoptelea. Monoploid genome size also varies among the smaller genera, but it is consistent within Zelkova, the only other genus with more than one species (Table 2; Fig. 1). Flow cytometry may thus be useful in placing species in their correct genus or subgenus, checking identification of sterile elms, and checking the parentage of putative hybrids between different subgenera of Ulmus.

This preliminary survey confirms variable ploidy in the two species where it has been reported previously, U. americana and Hemiptelea davidii. The ploidy variation in Hemiptelea davidii, together with the low pollen stainability reported by Fu et al. (1998), make it seem that reproduction in this species may follow some unusual genetic process; for example, apomixis is often associated with high ploidy levels and low pollen viability (Savidan et al., 2001). Tetraploid U. americana, in 
contrast, is well known to reproduce sexually in the normal way (Ager and Guries, 1982; Shattuck, 1905).

No evidence was found of cryptic variation in any other species, such as that recently demonstrated within U. americana (Whittemore and Olsen, 2011), although more extensive sampling within the species will be required to completely rule this out. The single triploid tree of $U$. microcarpa is not too surprising because rare polyploid individuals are found in other elm species (Ehrenberg, 1949; A.T. Whittemore, unpublished data). Additional study of $U$. microcarpa was not possible because tissue suitable for flow cytometry could only be obtained from the one tree.

These results confirm the uniqueness of tetraploid $U$. americana in this otherwise diploid genus, already commented on by many authors (Santamour and Ware, 1997).

The flow cytometry results from the two samples of $U$. villosa do not support the inclusion of this poorly known Himalayan species in subg. Oreoptelea, where it was placed by Grudzinskaya (1974) and Richens (1983). The diploid genome of $U$. villosa is only $\approx 2.2 \mathrm{pg}$, much smaller than any of the other diploid elms tested (3.0-4.2 pg). Morphologically, this species does not fit into either of the recognized subgenera (see above). Its genome size, which differs sharply from all other elm species, and its ambiguous morphology both provide evidence of a relatively strong overall genetic divergence from the remaining species of the genus. Further investigation will probably show that a third subgenus will be needed to accommodate this single species. Because of its remote position and strong genomic differentiation, $U$. villosa may be a potential source of novel characteristics not found in other elms.

In contrast, the genome of $U$. elongata $(2 \mathrm{C}=3.00)$ measured from the one available sample is similar in size to genomes of species placed in subg. Oreoptelea, but it is much smaller than the genomes of species in subg. Ulmus. This supports the conclusion of $\mathrm{Fu}$ et al. $(1979,1998)$ that $U$. elongata is related to a group of North American species, and it should be placed in Ulmus subg. Oreoptelea as defined by Wiegrefe et al. (1994). This poorly known species is thus confirmed to be the only close relative of $U$. americana native to eastern Asia, where DED originated. As previously mentioned, study of the response of $U$. elongata to DED infection could be valuable. If it shows resistance to DED fungi, as might be expected for an elm native to eastern Asia, any resistance genes found in the species are expected to be more compatible with the genetic background of $U$. americana and other species of subg. Oreoptelea than the species of subg. Ulmus, the only DED-resistant species that have been studied to date. Research into how U. elongata responds to inoculation with DED fungi could improve our understanding of survival strategies that are viable in the species of Ulmus subg. Oreoptelea. Furthermore, breeding with $U$. elongata could potentially produce disease-tolerant elms with characteristics of $U$. americana, something that has not been accomplished by crossing $U$. americana with members of subg. Ulmus.

In its native range in China, U. elongata is uncommon and its habitat is highly fragmented, and it is legally protected (Gao et al., 2012). Limited germplasm is available in the United States (possibly all cuttings from a single tree). This germplasm is being propagated, and it is hoped that it can be distributed to multiple sites, so the germplasm will be more secure and available for future research.

This study demonstrates consistent genomesize differences between subgenera of Ulmus and related genera that can be used to clarify the taxonomic placement of species whose relationships are ambiguous. It also indicates that $U$. elongata may be a valuable target for future research and breeding of North American members of Ulmus subg. Oreoptelea (most New World elms). On the other hand, $U$. villosa may be a good source of novel alleles in Ulmus, but should not be expected to show strong genetic compatibility with other species of the genus. At the same time, these results confirm the overall conservatism of genome-size evolution in Ulmus and related genera.

\section{Literature Cited}

Ager, A.A. and R.P. Guries. 1982. Barriers to interspecific hybridization in Ulmus americana. Euphytica 31:909-920.

Bob, C.F., B.L. Redmond, and D.F. Karnosky. 1986. On the nature of intra- and interspecific incompatibility in Ulmus. Amer. J. Bot. 73 (4):465-474.

Brasier, C.M. 1991. Ophiostoma novo-ulmi sp. nov., causative agent of current Dutch elm disease pandemics. Mycopathologia 115:151-161.

Brasier, C.M. 2001. Rapid evolution of introduced plant pathogens via interspecific hybridization. Bioscience 51:123-133.

Campanella, T.J. 2003. Republic of shade: New England and the American elm. Yale Univ. Press, New Haven, CT.

Chesnay, C., A. Kumar, and S.R. Pearce. 2007. Genetic diversity of SIRE-1 retroelements in annual and perennial Glycine species revealed using SSAP. Cell. Mol. Biol. Lett. 12:103-110.

Deligen. 2006. Red Hemiptelea davidii-A desert specific tree species [in Chinese]. Inner Mongolia J. For. 2006:4.

Denk, T. and G.W. Grimm. 2005. Phylogeny and biogeography of Zelkova (Ulmaceae sensu stricto) as inferred from leaf morphology, ITS sequence data and the fossil record. Bot. J. Linn. Soc. 147:129-157.

Dolezel, J., J. Greilhuber, and J. Suda. 2007a Estimation of nuclear DNA content in plants using flow cytometry. Nat. Protoc. 2(9):22332244.

Dolezel, J., J. Greilhuber, and J. Suda. 2007b. Flow cytometry with plant cells. Wiley, Weinheim.

Dunn, C.P. (ed.). 2000. The elms: Breeding, conservation, and disease management. Kluwer Academic Publishers, Boston, MA.

Ehrenberg, C.E. 1949. Studies on asynapsis in the elm, Ulmus glabra Huds. Hereditas 35:1-26.

Fu, L., C. Chen, and Y. Tang. 1979. Materiae ad floram Ulmacearum Sinensium. Zhiwu Fenlei Xuebao 17(1):45-51.
Fu, L., C. Chen, Y. Tang, and K. Kuang. 1998. Ulmus, p. 335-377. In: W.-Y. Chun and C.-C. Huang (eds.). Flora republicae popularis sinicae. vol. 22. Science Press, Beijing, China.

Fu, L., Y. Xin, and A.T. Whittemore. 2004. Ulmus, p. 1-19. In: W. Zheng-yi and P.H. Raven (eds.). Flora of China. vol. 5. Missouri Botanical Garden Press, St. Louis, MO.

Gao, J.-G., Y.-H. Wu, G.-D. Xu, W.-Q. Li, G.-H. Yao, J. Ma, and P. Liu. 2012. Phylogeography of Ulmus elongata based on Fourier transforminfrared spectroscopy (FTIR), thermal gravimetric and differential thermal analyses. Biochem. Syst. Ecol. 40:184-191.

Godfrey, R.K. 1988. Trees, shrubs, and woody vines of northern Florida and adjacent Georgia and Alabama. Univ. of Georgia Press, Athens, GA.

Goldblatt, P. and D.E. Johnson (eds.). 1979. Ulmaceae. In: Index to plant chromosome numbers. Missouri Botanical Garden, St. Louis, MO. $<$ http://www.tropicos.org/Name/42000050? projectid $=9>$.

Greilhuber, J., J. Dolezel, M.A. Lysák, and M.D. Bennett. 2005. The origin, evolution and proposed stabilization of the terms 'genome size' and 'C-value' to describe nuclear DNA contents. Ann. Bot. (Lond.) 95:255-260.

Grudzinskaya, I.A. 1974. On taxonomic position and area of the section Chaetoptelea, genus Ulmus [in Russian]. Botanicheskiy Zhurnal (Leningrad) 59:61-66.

Hans, A.S. 1981. Compatibility and crossability studies in Ulmus. Silvae Genet. 30:4-5.

Heybroek, H.M. 2015. The elm, tree of milk and wine. In: A. Santini, L. Ghelardini, E. Collin, A. Solla, J. Brunet, M. Faccoli, A. Scala, S. De Vries, and J. Buiteveld (eds.). The elms after 100 years of Dutch Elm disease. Proc. III Intl. Elm Conf., Florence. Italian Soc. Silviculture and For. Ecol. doi: 10.3832/ifor1244-007.

Karrfalt, R.P. and D.F. Karnosky. 1975. Meiotic pairing and chromosome morphology in American elm. For. Sci. 21:123-127.

Mittempergher, L. 2000. Elm yellows in Europe, p. 103-120. In: C.P. Dunn (ed.). The elms: Breeding, conservation, and disease management. Kluwer Academic Publishers, Boston, MA.

Oginuma, K., P.H. Raven, and H. Tobe. 1990. Karyomorphology and relationships of Celtidaceae and Ulmaceae (Urticales). Bot. Mag. Tokyo 103:113-131.

Richens, R.H. 1983. Elm. Cambridge Univ. Press, Cambridge, UK.

Santamour, F.S., Jr. 1969. New chromosome counts in Ulmus and Platanus. Rhodora 71:544-547.

Santamour, F.S., Jr. 1979. Resistance of Himalayan small-leaved elm to Dutch elm disease. J. Arboric. 5:110-112.

Santamour, F.S., Jr. and G.H. Ware. 1997. Chromosome numbers of new Ulmus (elm) taxa introduced from China. Rhodora 99:148-151.

Savidan, Y., J.G. Carman, and T. Dresselhaus (eds.). 2001. The flowering of apomixis: From mechanisms to genetic engineering. Mexico City: CIMMYT, IRD, European Commission DG VI (FAIR).

Shattuck, C.H. 1905. A morphological study of Ulmus americana. Bot. Gaz. 40(3):209-223.

Sherald, J.L., F.S. Santamour, Jr., R.K. Hajela, N. Hajela, and M.B. Sticklen. 1994. A Dutch elm disease resistant triploid elm. Can. J. For. Res. 24:647-653.

Sherman-Broyles, S. 1997. Ulmus, p. 369-375. In: FNA Editorial Committee (ed.). Flora of North America. vol. 3. Oxford Univ. Press, New York, NY.

Sinclair, W.A. 2000. Elm yellows in North America, p. 121-136. In: C.P. Dunn (ed.) 
The elms: Breeding, conservation, and disease management. Kluwer Academic Publishers, Boston, MA.

Smalley, E.B. and R.P. Guries. 2000. Asian elms: Sources of disease and insect resistance, p. 215230. In: C.P. Dunn (ed.). The elms: Breeding, conservation, and disease management. Kluwer Academic Publishers, Boston, MA.

Song, Q., G. Jia, Y. Zhu, D. Grant, R.T. Nelson, E.-Y. Hwang, D.L. Hyten, and P.B. Cregan. 2010. Abundance of SSR motifs and development of candidate polymorphic SSR markers (BARCSOYSSR_1.0) in soybean. Crop Sci. 50:1950-1960.
Thiers, B. 2016. [continuously updated]. Index Herbariorum: A global directory of public herbaria and associated staff. New York Botanical Garden's Virtual Herbarium. 20 Sept. 2016. $<$ http://sweetgum.nybg.org/science/ih/>.

Townsend, A.M. 1975. Crossability patterns and morphological variation among elm species and hybrids. Silvae Genet. 24:18-23.

Ware, G.H. 1995. Little-known elms from China: Landscape tree possibilities. J. Arboriculture 21:284-288.

Warren, K. 2000. The return of the elm: Status of elms in the nursery industry, p. 341-348. In: C.P. Dunn (ed.). The elms: Breeding, conservation, and disease management. Kluwer Academic Publishers, Boston, MA

Whittemore, A.T. and R. Olsen. 2011. Ulmus americana (Ulmaceae) is a polyploid complex. Amer. J. Bot. 98:754-760.

Wiegrefe, S.J., K.J. Sytsma, and R.P. Guries. 1994 Phylogeny of elms (Ulmus, Ulmaceae): Molecular evidence for a sectional classification Syst. Bot. 19(4):590-612.

Wiegrefe, S.J., K.J. Sytsma, and R.P. Guries. 1998. The Ulmaceae, one family or two? evidence from chloroplast DNA restriction site mapping. Plant Syst. Evol. 210:249270 . 